\title{
Kuşak Değişimi Bağlamında Kentsel Kamusal Mekânı Yeniden Düşünmek
}

\author{
Rethinking Urban Public Space in the Context \\ of Generational Change
}

\section{Selin Karaibrahimoğlu}

Giresun Üniversitesi Teknik Bilimler Meslek Yüksekokulu, Mimarlık ve Şehircilik Bölümü, Giresun

ÖZ

Özünde insan için tasarlanan mekân, özellikle de kentsel kamusal mekân devingen bir yapıya sahiptir, zaman içinde dönüşür. Mimari mekân tek bir birey için tasarlanırken kentsel mekân toplumun ortak beklentilerini karşılamak üzere tasarlanır ve bu süreçte toplumsal tercihler belirleyici olur. Tercihleri etkileyen en önemli değişkenlerden biri ise kuşaklardır. Bu kapsamla çalışmanın amacı içinde bulunduğumuz dönemde bir arada yaşayan, toplumu oluşturan $X, Y$ ve $Z$ kuşaklarının kentsel kamusal mekândan beklentilerinin ve bu beklentilerin ne ölçüde ve ne yönde değiştiğinin ya da değişmediğinin, bu değişimin nedenlerinin karşılaştırmalı bir bakış açısıyla belirlenmesidir. Çalışma kuşakların kamusal mekândan beklentilerinde ve mekânı kullanım şekillerinde farklılıklar olduğu hipotezinin sınanması üzerine kurgulanmıştır. Alan çalışması Giresun'da gerçekleştirilmiş ve $X, Y$ ve $Z$ kuşaklarının her birini temsil eden, 30'ar kişi ile toplam 90 anket yapılmıştır. Anket sonucu elde edilen veriler karşılaştırılarak, kuşakların tercihleri belirlenmiş, nedensellikleri çözümlenmiştir. Böylece kentsel kamusal mekâna yönelik tasarım kararlarını etkileyecek yeni bakış açıları ve öneriler oluşturmaya yönelik bir tartışma ortamı yaratılmıştır.

Anahtar sözcükler: Kentsel kamusal mekân; $X, Y$ ve $Z$ kuşağı; kullanıcı tercihleri.

\section{ABSTRACT}

The place that is designed for humans at the core has a dynamic structure, especially within the urban public space, and is converted over time. However, although the architectural space is designed in line with the wishes and needs of a certain number of people, urban public space is designed to meet the common expectations of the society, and social preferences come to the forefront. One of the important variables that affect preferences is the generations. With this viewpoint, the aim of the present study was to discuss the expectations of $X, Y$ and $Z$ generations, who live together in our present time, and the extent and changes in these expectations (if any), and the reasons for this change from a comparative perspective. The study was based on testing the hypothesis that there are differences in the expectations of generations from public space and the way they use it. The field study was conducted in Giresun, and a total of 90 questionnaires were conducted with 30 people who represented each of the $X, Y$ and $Z$ generations. By comparing the data obtained in the questionnaires, the preferences of generations were determined and their causality was analyzed. In this way, a discussion medium was created to form new perspectives and suggestions that would affect design decisions for urban public space. Keywords: Urban public space; generations $X, Y$ and Z; user preferences. 


\section{Giriş}

Mekân basit bir tanımlamayla boyutları, sınırları olan fiziksel bir olgu olarak nitelenebilir. Ancak bu fiziksel olgu insan yaşamını, davranışını yönlendirme ve etkileme gücüne sahiptir. Bu gücü fiziksel bileşenlerinin bir araya gelişini hazırlayan işlevsel, anlamsal, boyutsal gereklilikleri içeren, onları özümseyen süreç aracılığı ile kazanır. Dolayısıyla fiziksel bir olgu olmanın ötesinde anlamlar içerir. Öyle ki toplumsal bir ürün olarak zihinsel olanla kültürel olanı, toplumsalla tarihseli birbirine bağlayan mekân (Lefebvre, 2014) kendisini oluşturan bileşenler aracılığıyla ve üretildiği toplumun kültürel, ekonomik, psikolojik ve tarihsel bağlamı üzerinden yeni anlamlar kazanır. Bu anlamsal içeriği etkileyen en önemli değişken mekânın kim için ve hangi amaca hizmet etmek için tasarlandığıdır. Mimari mekân belli kişi ya da kişiler için tasarlanırken, kentsel kamusal mekân toplum için tasarlanır. Bu nedenle kentsel kamusal mekânın tasarımında toplumun ortak ihtiyaçları yönlendirici olmaktadır. Ancak küreselleşme ve teknolojik gelişmelerin etkisiyle pek çok modern kentin bile çok boyutlu bir değişim sürecinden geçtiği günümüzde, ülkemizde de kentsel kamusal mekânlarda hızlı bir dönüşüm gerekli görülmekte, çağın istek ve gerekliliklerine cevap veren yeni mekânsal ihtiyaçlar gündeme gelmektedir.

Özellikle insanların fiziksel anlamda bir arada bulunma, sosyalleşme gibi ihtiyaçlarını sanal ortamlarda gerçekleştirmeye başlaması ve bu durumun toplumsal bireyselleşmeyi yaygınlaştırması; kentsel kamusal mekânın kabuk değiştirmesine, kimi işlevlerini yitirirken yeni işlevler kazanmasına neden olmaktadır. Oysa kentsel kamusal mekânın ihtiyaçları karşılamadaki yeterliliği ve bu sayede kazandığı cazipliği bireyler arasındaki iletişimi, etkileşimi olumlu yönde etkileyecek bir potansiyel sunmaktadır. Dolayısıyla günümüzde binalar arasında kalan sokak, meydan, park gibi açık alanları tanımlayan; kentlinin toplanacağı, karşılaşacağı, iletişimde ve etkileşimde bulunacağı, kültürel bir üretim gerçekleştireceği kentsel kamusal mekânların tasarımı daha da önem kazanmaktadır. Kentsel kamusal mekânın toplumun ortak beklentilerini karşılayabilmesi, toplumsal tercihleri ön plana çıkarması, Erzen'in (2019) kent tanımında kullandığı ifadeye benzer bir anlatımla, çoklukları homojenleştirmeden ve birbirinden ayırmadan bir arada yaşatabilmesi ve insancıl bir ortam sunması gerekir. Bunu sağlamanın yolu hem fiziksel hem de psikolojik açıdan kullanıcının isteklerine, beklentilerine ve ihtiyaçlarına cevap verecek esnek mekânlar tasarlamaktan geçmektedir. İşte bu noktada kullanıcının kim olduğu ve özellikleri önem kazanır. Cinsiyet, yaş, sosyal statü, eğitim durumu, kuşak gibi değişkenler kullanıcı özelliklerini tanımlarken, bunlar arasında "kuşak" sahip olduğu toplumsal içerikle farklı bir konuma sahiptir. Çünkü kuşak aynı dönemde aynı toplumsal koşullar içerisinde, benzer kaygılar ya da öncelikler ile yaşamış insan gruplarını tanımlamaktadır. Yaşanan dönemin ekonomik, kültürel, politik ve teknolojik durumunun belirlediği toplumsal koşullar kişilerin hayata bakışını, bununla ilişkili olarak da isteklerini, ihtiyaçlarını ve beklentilerini farklılaştırmakta, aynı zamanda mekânsal tercihlerini de etkilemektedir. Bu anlamda sahip olduğu toplumsal içerikle, kentsel kamusal mekânın bilinen genel tasarım kriterlerine uygun olmasının dışında kuşakların değişen mekânsal tercihlerine de cevap verecek özelliklere sahip olması beklenmektedir.

$\mathrm{Bu}$ bakışla kuşak kavramı çalışmanın odağına yerleştirilmiş, Türkiye'de kentsel kamusal mekânların nitelikleri ve kuşakların ihtiyaçları temel tartışma alanı olarak belirlenmiştir. Çalışma kuşakların kamusal mekândan beklentilerinde ve mekânı kullanım şekillerinde farklılıkların olduğu hipotezinin sınanması üzerine kurgulanmıştır. İçinde bulunduğumuz dönemde bir arada yaşayan ve toplumun büyük bir kesimini oluşturan $X$, $Y$ ve $Z$ kuşaklarının kentsel kamusal mekândan beklentilerinin neler olduğunun, kuşaklar arasında bu beklentilerin ne ölçüde ve ne yönde değiştiğinin ya da değişmediğinin, bu değişimin nedenlerinin karşılaştırmalı bir bakış açısıyla tartışılması çalışmanın amacıdır. Giresun'da gerçekleştirilen çalışmanın hipotezi $X, Y$ ve $Z$ kuşaklarının her birini temsil eden; eğitim, cinsiyet dağılımı açısından dengeli bir örneklem oluşturan 30'ar kişi ile yapılan toplam 90 anket üzerinden sınanmıştır. Ankette mekânın kullanımını etkileyen değişkenler ve kullanıcının zamansal tercihleri sorgulanmış, elde edilen veriler karşılaştırmalı bir bakış açısıyla nedensellikleri üzerinden değerlendirilmiştir. Böylece kentsel kamusal mekâna yönelik tasarımları etkileyecek yeni bakış açılarının ve önerilerin tartışıldığı bir ortam oluşturulmuştur.

\section{Kentsel Kamusal Mekân ve Kullanıcısı Olarak "Kuşaklar"}

Kentler, binalardan ve bu binalar arasında kalan boş açık alanlardan oluşur. Binalar arasında kalan açık alanlar dış mekân ya da kentsel mekân olarak tanımlanmakla beraber; toplumun ortak özelliklerine ve mekânın fiziksel olanaklarına göre işlevsel ve yapısal olarak sınırları belirlenmiş, simgesel anlamlar taşıyan oluşumlardır. İnsan eserinin 'boşlukları sınırladı̆̆ı' her yer; sokaklar, meydanlar, caddeler, parklar ve bahçeler kentsel yaşamın sürdüğü kentsel mekânlardır (Zevi, 1990). Sosyal bir kurgunun parçası olarak taşıdığı kamusallık dışında mekânsal niteliklere de sahip kamusal mekân; pek çok araştırmacı tarafından politik, fiziksel, anlamsal, mülki ve toplumsal boyutlarıyla kimi zaman farklı kavramsal açılımlarla, kimi zaman da tüm bu özelliklerini içeren genel yaklaşımlarla tanımlanmıştır.' Ancak bu tanımlamaların ortak noktası kentsel mekânın

Bu yaklaşımlara kamusal mekânı; görsel algısı ile ilgili olarak tanımlayan Cullen'in (I96I), fiziksel özellikleri ve sınıflandırılması üzerinden tanımlayan Krier'in (I979), sosya etkileşim boyutu ile ilişkili olarak tanımlayan Jacobs'un (1964), insan ihtiyaçları açısından tanımlayan Lang'in (1994) ve sınırlayıcıların çeşitleri ve nitelikleri üzerinden tanımlayan Joedicke'nin (1985) yaklaşımları örnek verilebilir 
yaşayan bir organizma olarak kabul edilmesi ve kullanımının herkese açık olmasıdır. Lefebvre'in (20।4) değindiği gibi mekân toplumsal bir üründür ve kamusal mekân toplumsal mekân tanımıyla özdeşleştirilmelidir. O'na göre yaratılan yeni mekânlar aynı zamanda yeni toplumsal ilişkileri tanımlar. Tanyeli (2009) kamusal mekânı kullanımı herkese açık olan; üstelik içinde bulunan kişilerin organik toplumsal bağla birbirleriyle ilişkili olmadığı fiziksel bir olgu olarak tanımlar. Burada tanımlanan; "organik toplumsal bağla birbiriyle ilişkili olmayan insanların kurduğu yeni toplumsal ilişkiler" zamanın gerekleri ile yeni sosyalleşme şekillerini ve yaşam ritüellerini belirler. Böylece kamusal mekânın kullanımı sağlanır ve insan fiziksel varlığı ile kentsel kamusal mekânın parçası olarak onu yaşatır (Erzen, 2019). Doğası gereği başkalarıyla beraber olma eğiliminde olan insan, yaş, cinsiyet, ırk vb. özellikleri dışında kendi ihtiyaçlarını karşılama durumuna göre mekânı seçer, orada insanlarla görsel-işitsel temas kurar ve sosyalleşir.

Bu kapsamla kent yaşamının ayrılmaz bir parçası olan kentsel kamusal mekânın tüm niteliklerinin özünde doğrudan kentte yaşayan insanın belirleyici olduğu söylenebilir. Zirâ, kentsel yaşamı tanımlayan kentsel süreçlerin oluşturduğu sistem ancak bir bütün olarak, insan odaklı, açık mekân yaşantısı ile ilgili beklentilere cevap verecek şekilde planlandığında ve tasarlandığında işleyen bir sisteme dönüşmektedir (Erdönmez ve Akı, 2005). Sistem içindeki ilişki, tamamlanmış ve anlaşılır olduğunda, mekânsal ilişkiler başarıyla kurgulanır ve bu şekilde parçalar tek bir çerçeve içinde birleştirilerek kimlik kazanır. Bu nedenlerle kentsel mekânın tasarımı ve çağa uyum sağlama düzeyi önem kazanmakta; kullanıcı özellikleri ve ihtiyaçları kamusal mekânın kullanılabilirliğinin sağlanmasında belirleyici olmaktadır. Tam da bu noktada kullanıcıyı ihtiyaçları, hayata bakışı, yaşanmışlıkları ile tanımlayan "kuşak" kavramı karşımıza çıkar.

Türk Dil Kurumu’nun “yaklaşık olarak aynı yıllarda doğmuş, aynı çağın şartlarını, dolayısıyla birbirine benzer sıkıntıları, kaderleri paylaşmış, benzer sorumluluklarla yükümlü olmuş kişiler topluluğu" olarak tanımladığı (URLI) kuşak kavramını; Mannheim (1998) da, benzer bir yaklaşımla, ortak alışkanlıkları ve kültürü paylaşan insanlar topluluğu olarak tanımlar. Diğer bir tanıma göre ise kuşaklar; tarihte zaman ve mekân paylaşan ve onlara toplu bir kişilik kazandıran ortak değer, inanç ve davranışlara sahip bir grup insandır (Tessler vd., 2004). Kuşaklar arasında yetişme tarzları ve içinde bulundukları ortam değişiklikleri nedeniyle gerek karakter, gerek olaylara yaklaşım ve gerekse beklentiler konusunda önemli farklılıklar gözlenmektedir (Keleş, 20I I). Eğitim, cinsiyet ve etnik köken unsurları gibi insana özgü değişkenler nedeniyle bu farklılıkları net ve kesin çizgilerle sınırlamak çok doğru bir yaklaşım olmasa da (Parry ve Urvin, 2010), yapılan pek çok araştırma farklı kuşaklardaki kişilerin ait oldukları kuşağın özelliklerini, her ne kadar dışarıdan o şekilde görülmeseler de, benzersiz ve tek olarak gösterdiklerini kanıtlamaktadır (URL 2). Bu bakışla tüm tanımlamaları ve daha birçok araştırmacının konuya yaklaşımını belirleyen ortak noktanın kuşak kavramının sahip olduğu güçlü sosyolojik içerik olduğu söylenebilir.

Kuşaklar doğdukları yıllara göre tanımlandıklarında farklı araştırmacılar, farklı yaklaşımlarla farklı gruplamalar yapmış olsa da genelde; 1946-1964 arası "Bebek Patlaması Kuşağı”, 19651979 arası "X Kuşağı”, 1980-1999 arası "Y Kuşağı” ve 20002020 arası doğanlar ise "Z Kuşağı" olarak adlandırılmaktadır (Twenge vd., 20l0). Ancak çalışmaya günümüzde bir arada yaşayan ve toplumun büyük bir kesimini oluşturan kent yaşamında etkin rol oynayan, $X, Y$ ve $Z$ kuşakları ve kentsel kamusal mekândan beklentileri konu edilmiştir.

\section{I. X Kuşağı (1965-1979)}

Başlangıçta bir İngiliz müzik grubunun ismi olarak ortaya çıkan "X" tanımı, ilk defa 1989 yılında Coupland tarafından bir kuşak adı olarak kullanılmıştır (URL 3). Kuşak döngüsünde bireyciliği temsil eden X kuşağı (Kuran, 20I0) bir önceki kuşaktan farklı olarak cinsiyet rollerinde ve aile yapılarında değişimlere tanık olmuşlardır. Kuşağın erkek temsilcileri babalarından farklı olarak aile hayatı ve çocuk bakımında daha fazla görev üstlenmişlerdir (Kon, 20I7). Genellikle çalışan ebeveynlerin çocuklarıdırlar. Ebeveynleri olmadan kendi başlarına okuldan eve gidip gelerek kendi başlarına büyümeyi öğrenmişlerdir (Toruntay, 20II). Erken yaşta yetişkin olmuşlar, önceki kuşaklara göre ailelerinin sorumluluğunu daha çabuk üstlenmiş (Raines, 2002), daha geç evlenmiş ve daha geç çocuk sahibi olmuşlardır. Aile içi tartışmalarda eşit katılımcı olmalarına izin verilen, erken yaşlarda görüşlerini dile getirmeyi ve kendilerini ifade etmeyi öğrenen $X$ kuşağı görüşlerinin dikkate alınmasını önemser (Bezirci, 2012). Coupland'a göre kendini topluma zıt gören, sert politik çıkışlar yapan, farklı bir imaj tercih eden, daha baskın müzik çeşitleri ve değişik yaşam tarzları gibi topluma kendilerini aykırı hissettirecek tercihlerde bulunan ve farklı yaşayış biçimlerine sahip bir kuşaktır (Coupland, 1989). Bu kuşağın bireylerinin temel tutumları ve değerleri arasında bireyselcilik, pragmatizm, olumsuzculuk, farklı yaşam biçimlerine karsı hoşgörü ve kültürel çeşitlilik yer almaktadır (Toruntay, 20I I). Olabildiğince kanaatkâr, toplumcu, sadık ve idealistlerdir. Kendisi dışındaki kuşakları anlamak için çaba harcamazlar (Elmore, 201 I; Düzenli vd., 2020). Ülkemizin \%22'sini oluşturan (URL 4) yetişkin ve orta yaşlı (40-55 yaş arası) olarak tanımlanan yaş grubunu temsil eden $X$ kuşağı Türkiye'de geçiş dönemi çocukları olarak da adlandırılmaktadırlar. Bunun nedeni söz konusu yıllarda hem dünyada hem de Türkiye'de petrol krizleri, ekonomik sarsıntılar, üniversite olayları, sol-sağ çatışması ve televizyon döneminin başlaması gibi gelişmelerin başlattı̆̆ı bir geçiş sürecinin yaşanmasıdır (Delahoyde, 2009; Türk, 20I3). Öte yandan bu dönemin koşulları bireylerin davranışları üzerinde farklı etkiler yaratmış, bireyler parasal konular dışında, 
sosyal yaşamla ilgili unsurlara önem vermeye başlamışlardır (Kon, 20I7). Bu nedenle toplumsal sorunlara karşı duyarlı bir kuşaktır. Türkiye'de bu kuşağın kadınları yoğun olarak iş gücüne katılmaya başlamış, daha iyi yaşamak için daha az çocuk sahibi olmuşlardır (Mengi, 2009). İş dünyasında yer elde edebilmek için mücadele veren kadınların çocukları olan X'ler, “cinsiyet eşitliği” ile ilk tanışan nesildir (Kon, 2017). Daha çok, yaşamak için çalışmakta, kendi sorunlarını kendileri çözmektedirler. Bu nedenle de kendilerine güvenleri ve iş yapabilirlikleri daha yüksektir (Toruntay, 20II). Bu kuşağın üyeleri tek başlarına çok iyi çalışırlar, sabırsızdırlar ve iş motivasyonları yüksektir (Çetin Aydın ve Başol, 20।4). Günümüzde kullanılan teknolojik ürünlerin çoğunu bu kuşak üyeleri geliştirmiş olmalarına rağmen, teknolojiyi kullanmada $Y$ kuşağının çok gerisinde kalmışlardır. Ancak genel olarak $X$ kuşağı bireylerinin, teknoloji ve bilgi ile barışık, girişimci, amaç odaklı ve bağımsız oldukları söylenebilir (Jianrui, 20II). X kuşağını kısaca daha çok risk alan; geçerli ritüel ve gelenekler gibi otoriteleri önceki kuşaklara göre daha çok sorgulama eğiliminde olan, ancak onlara saygı duyan; aile odaklı, açık fikirli ve eğlenmeyi seven (Zhang ve Bonk 20I0; Etlican, 20I2), kurallara uyumlu, aidiyet duygusu güçlü, sadık ve çalışkanlığa önem veren bir kuşak olarak tanımlamak mümkündür (Düzenli vd., 2020).

\subsection{Y Kuşağı (1980-1999)}

Her şeyi sorguluyor olmalarından dolayı "WHY” kuşağı olarak tanımlanmış, kısaca ' $Y$ kuşağı' olarak adlandırılmışlardır (Kuru, 20I4). “Internet kuşağı”, “Milenyum Kuşağı”, “Gelecek Kuşak”, "Dijital Kuşak” gibi farklı isimlerle de tanımlanan Y kuşağının, (Morgan, 20II) yaşam şartlarında meydana gelen değişim ve dönüşümler diğer kuşaklardan farklı beklentilere, ümitlere ve tercihlere sahip olmalarına neden olmuştur (Kon, 2017). Bu nedenle hem gündelik yaşamı hem de iş yaşamı yeniden biçimlendiren bir kuşak olarak tanımlanmaktadırlar. İçinde bulunduğu topluluğu etkileme ve onlardan etkilenme eğilimi yüksek, harekete geçmek için anlam arayan bir kuşaktır (Kuran, 20l0). Her şeyi elde etme ve dönüştürebilme gücüne sahip olduklarına inanan bu kuşak, ebeveynlerinden farklı olarak modern teknolojiler ve tüketim toplumu tarafindan kuşatılmış bir çevrede büyümüşlerdir (Çetin Aydın ve Başol, 20I4). Internetin olduğu yıllarda dünyaya gelen ilk kuşaktır, bu nedenle dünyanın her köşesi ile iletişimin mümkün olduğu bir dönemde, farklı kültürlerle etkileşime girerek, kültürel zenginliklerini artırmışlardır. Aynı zamanda medya ve reklam etkisinde büyüyen, ilk kez internet alışverişi yapan $Y$ kuşağının marka algısı ve seçiciliği çok yüksektir. Bu durum gelir seviyesi farklılığının daha önce olmadığı kadar nesneler üzerinden görünür hale gelmesine neden olmuştur (Toruntay, 20I I). İyi bir gelirden çok, yaptıklarının onaylanması, teşvik edilmek, takdir edilmek en önemli gereksinimleridir (Keleş, 20II). Teknolojinin günlük yaşama girişi ve artan hızı bu kuşağı hızlı düşünmeye, hızlı hareket etmeye ve dolayısıyla da hızlı tüketmeye yöneltmektedir. X kuşağı gibi çalışan anne babaya sahip $Y$ kuşağının ebeveynlik yaşı yükselmiştir. Bu kuşak, çocuğunun iyi şartlar altında büyüyebilmesi, iyi bir eğitim alması ve güvende olması konusunda çok daha aktif rol oynayan; koruyucu, okul başarısı konusunda kontrolcü ve sorgulayıcı anne babalara sahiptir. Literatürde bu kuşağı yakından takip ederek yetiştiren ve sürekli etrafında olan ebeveynlere "Helikopter Ebeveynler" (Helicopter Parents) denmektedir (Howe ve Strauss, 2007). Üniversiteye devam eden ve tamamlayan oranı diğer kuşaklara göre daha yüksektir. İnsan hakları konusunda artan bilinç kuşak üyelerine hangi durumda olurlarsa olsunlar söylenen son sözün hiçbir zaman aslında son söz olmadığını öğretmiştir (Wendover, 200I). Ülkemiz nüfusunun \%35'ini oluşturan Y kuşağı bu oranla Avrupa'nın pek çok ülkesinin toplam nüfustan daha fazla sayıya ulaşmıştır (URL 4). Bu kuşağın belirleyici olayları, terörizm, kahramanlık, vatanseverlik ve global bağlantılardır. Türkiye'de artan terör olayları, Körfez Savaşı, Irak Savaşı, Sovyet Sosyalist Cumhuriyetler Birliği'nin dağılışı, Berlin Duvarı'nın yıkılışı, internetin kullanımı, küreselleşen dünya ve cep telefonunun icadı bu kuşağı etkileyen başlıca olaylardır. Özellikle 12 Eylül 1980 ihtilali sonrasında Türkiye'de siyasal ve ekonomik yaşamı derinden etkileyen 24 Ocak kararları ile karma ekonomik sistemden serbest piyasa ekonomisine geçiş yaşanmasının $Y$ kuşağı üzerinde önemli etkileri olmuştur (Aktan, 20 I I). Dolayısıyla 1980 öncesindeki tüketim maddesi bulma güçlüğü gibi sıkıntıları yaşamayan $Y$ kuşağı, önceki kuşakların yaşadığı zorlukları anlamamaktadır (Toruntay, 20 I I). Daha önceki kuşaklara göre hem en meşgul, hem de en çok strese maruz kalmış kuşaktır (Raines, 2002). Sheahan'ın (2005) düşüncelerini ve hissettiklerini rahatlıkla ifade edebilen, sosyal ilişkileri seven ve duygusal zekâya sahip bireyler olarak tanımladığı Y kuşağı kısaca; özgürlüğüne düşkün, öğrenmeye istekli, otoriteye meydan okuyan, iyi eğitimli, ailesine değer veren, giyim, kuşam gibi prestij unsurlarına düşkün, kolay adapte olabilen, çabuk vazgeçen, sorgulayıcı, sabırsız, işbirlikçi ve ne istediklerini bilen bir kuşak olarak tanımlanabilir (Kon, 20 I7).

\subsection{Z Kusağı (2000-2020)}

2000 sonrası doğanların ( 20 yaş ve altı) oluşturduğu bu kuşak, önümüzdeki yıllarda yetişkin olacak ve çalışma yaşamına girecek gençleri ve çocukları kapsamaktadır (Kuran, 2010). Bu kuşağın üyelerine "Kuşak I”, “İnternet Kuşağı”, “Next Generation” ya da "i Gen”, “Instant Online (Her daim çevrimiçi)” gibi adlar verilmektedir (Levicate, 2010; Çetin Aydın ve Başol, 20।4). Z’leri diğerlerinden ayıran en önemli farklııı, değişimin çok hızlı ve hareketli bir seyir izlediği bir döneme tanıklık etmeleri ve daha doğmalarından çok önce hem kuşak teorisinin öngörülerine hem de kuşağın güncel davranış kalıplarına bakarak, daha yaratıcı, daha sahici, daha uyumlu olacaklarına dair öngörülerle özelliklerinin tanımlanabilmesidir (Kuran, 20l0). Z kuşağının en belirgin özelliği teknoloji ve yeni iletişim olanakları ile iç içe yaşıyor olma- 
larıdır. Mesafelerin önemini yitirmesine neden olan bu gelişmeler sayesinde internet olan her ortamda, herkesle görsel ve işitsel bağlantı kurabilmekte, ihtiyaçlarını bu şekilde karşılayabilmektedirler. Cep telefonu, tablet ve bilgisayar gibi teknolojik aletleri adeta vücutlarının bir uzvu gibi ileri derecede bir beceriyle kullanmakta, onlarsız kendilerini eksik hissetmektedirler. "Network" gençleri olarak kabul edilen Z kuşağı, sosyal ilişkilerini de uzaktan kurmakta, bu nedenle önceki kuşaklardan farklı olarak fiziksel olarak tek baslarına vakit geçirmektedirler. Dolayısıyla bu kuşağın aşırı bireyselleşme ile yalnız yaşamaya eğimli bir kuşak olacağı belirtilmektedir (Strauss ve Howe, 1991). Hayat standartlarında, özellikle teknolojik alanda, meydana gelen değişim ve dönüşümler Z kuşağı bireylerini diğer kuşaklardan ayrıştırmakta, apayrı bir dünyada yetişmelerine, bireysel özelliklerinin diğer kuşaklardan ayrılmasına neden olmaktadır (Ayhün, 20l3). Aynı anda birden fazla konuyla ilgilenebilme becerileri çok gelişmiş olan Z kuşağı, insanlık tarihinin el, göz, kulak vb gibi motor beceri senkronizasyonu en yüksek kuşağı olarak kabul edilmektedir. Ancak bu avantajlarının, zamanla dikkat ve konsantrasyon zorluklarıyla dezavantaja dönüşebileceği düşünülmektedir (Toruntay, 20II). Z kuşağı temsilcilerinin, Y'lerden farklı olarak yeryüzüne gelmiş en "bağlantılı"2 kuşak olmaları, sosyal ilişkilerini dâhi internet üzerinden sürdürmeleri gibi özellikleri diğer kuşakların onlarla iletişim kurmasını neredeyse imkânsızlaştırır (Türk, 20I3). Z kuşağı ülkemizin \% I7'sini oluşturan genç ve çocuk (2I yaş ve altı) olarak tanımlanan yaş grubunu temsil etmektedir. Eğitime önem veren, çok diplomalı Z kuşağı; yaratıcılığa izin veren aktivitelerden hoşlanmakta, sonuç odaklı hareket etmektedirler. Diğer yandan hak arama, farklı sosyolojik gruplarla ilişkiler konusunda da diğer kuşaklardan daha başarılı olmaları Z kuşağının iş hayatında başarılı olabileceklerini göstermektedir (Çetin Aydın ve Başol, 20I4). Kısaca dünya zevklerine düşkün, teknolojiyi hızlı şekilde kavrayan, birden fazla konuyla aynı anda ilgilenebilen, işlerini kısa sürede ve titiz biçimde yerine getiren, hem duyumsal hem nesnel olarak her şeyi çabuk tüketen tatminsiz bir kuşak olacakları tahmin edilmektedir. Hiyerarşiden hoşlanmamaları ise Z kuşağının yaşamlarında otorite kavramının öneminin kalmayacağının göstergesi olarak düşünülebilir (Kon, 2017).

Yukarıda ayrı ayrı ve kapsamlı şekilde irdelenen kuşak özellikleri her kuşağın farklı algı düzeyine, yönelime, kişilik özelliklerine, ihtiyaçlara ve bunların belirlediği farklı tercihlere sahip olduğunu göstermektedir. İnsanların, gereksinimleri ve beklentileri doğrultusunda çevrelerine uyum sağladıkları (Erdönmez, 2014) düşünüldüğünde hayatın her alanına yansıyan bu farklılıkların kentsel mekân tercihlerinde de belirleyici olması beklenmektedir. Bu nedenle çalışmada alan çalışması sonucu elde edilen veriler $X, Y$ ve $Z$ kuşaklarının genel özellikleri ve bunlarla ilişkili olarak farklılaşan ihtiyaçları bağlamında değerlendirilmiştir.

\section{Alan Çalışması}

Çalışmada veriler anket yoluyla ${ }^{3}$ elde edilmiştir. Anket çalışmasında kültür, eğitim gibi kişiye özgü faktörler araştırma dışı tutulmuş; her kuşağı temsil eden eşit sayıda kişiyle anket yapılmıştır. Giresun'da gerçekleştirilen çalışma, küreselleşme etkisinin, teknolojik gelişimin, iletişim olanaklarının artmasının insan davranışlarını, ihtiyaçlarını ve taleplerini benzer yönelimlerle belirlediği kabulü ile yere bağlı özelliklerden bağımsız kurgulanmıştır. Dolayısıyla araştırma sonuçları genel yönelimler hakkında bilgi verebilecek niteliğe sahiptir. Öte yandan çalışmada kentsel kamusal mekân olarak tanımlanan alan; park, bahçe, meydan gibi açık kamusal mekânlar ile sınırlandırılmış, ankete cevap verenler bu konuda bilgilendirilmiştir.

Kuşakların kamusal mekândan beklentilerinde ve mekânı kullanım şekillerinde farklılıkların olduğu hipotezini sorgulayan çalışmada anket soruları kentsel mekânın tercih edilme sebebinin çoğunlukla o mekânın fiziksel, sosyal ya da psikolojik özellikleri ile ilişkili olduğu düşüncesi bağlamında belirlenmiştir. Bu kapsamla kuşakların tercihleri; mekânı niteleyen özelliklerle ilişkili olarak ve toplumun her kesimi için geçerli olabilecek genel değişkenler bağlamında irdelenmiştir.

\section{I. Çalışmanın Değişkenleri}

İşlevsel ve yapısal olarak çeşitli fiziksel, toplumsal, simgesel özelliklerle sınırları belirlenen (Erdönmez, 20I4) kentsel kamusal mekânın öncelikle kullanılıyor olması, bunun için de kullanıcılarının ihtiyaçlarını karşılıyor olması gerekir. Carrr vd. (1992) kentsel kamusal mekâna yönelik en öncelikli ihtiyaçların rahatlık, dinlenme, aktif/pasif katılım, keşfetme ve insani ihtiyaçlar olduğunu belirtirken; Lang (1994), Maslow'un "ihtiyaç hiyerarşisi” ile ilişki kurarak bu ihtiyaçları fizyolojik ihtiyaçlar; emniyet ve güvenlik ihtiyacı; bağlılık, saygınlık ve kendini gerçekleştirme gibi ihtiyaçlar olarak sıralamıştır. Çubuk (1991) ise genel bir değerlendirme ile kentsel mekâna yönelik ihtiyaçları psikolojik, sosyal, ekonomik olarak sınıflandırmış ve erişilebilirliği sağlamanın öneminden bahsetmiştir. Kullanıcıların özgürce mekânı deneyimleyebilmeleri, kendilerini ifade edebilmeleri, gündelik aktivitelerini yapabilmeleri ve birbirleriyle iletişime geçebilmeleri ise Rapoport, (1977) tarafından tanımlanan kentsel mekâna yönelik sosyal ihtiyaçlardır. Kentsel kamusal mekânın tüm bu ihtiyaçları karşılama düzeyi kimi araştırmacı

2 İnternetten önceki zamanı bilmeyen Z kuşağı için internet bağlantısı gündelik hayatlarının ayrılmaz bir parçasıdır (Chicca ve Shellenbarger, 20ı8). İnternet ve sosyal medyayı çok yoğun olarak kullanırlar ve bağlantıları olmadan hayatın akışına katılamazlar. Onlar için sosyalleşmenin en etkili yeri dijital ortamlardır. Bu nedenle telefon, bilgisayar, tablet gibi cihazlar aracılığı ile sürekli bağlantıda bir hayat sürerler. Olağanüstü şekilde teknolojiye bağımlıdırlar ve ana dilleri teknolojik bir dildir (Reeves ve Oh, 2008). Bu özellikleri nedeniyle $Z$ kuşağı bağlantılı kuşak olarak nitelendirilmektedir.

3 Anket çalışması Mayıs 2020'de Giresun'da yaşayan katılımcılarla ve pandemi dönemi kısıtıılıkları nedeniyle çevrimiçi olarak gerçekleştirilmiştir. 
tarafından "kalite", kimi araştırmacı tarafından ise "yaşanırlık" kavramları ${ }^{4}$ ile tanımlanmakla beraber tüm bu kavramsal yaklaşımların ortak özelliği kentsel mekânın sahip olduğu özelliklerle ilişkilendirilmeleridir. Burada önemli olan kentsel mekânın çok boyutlu yapısının göz önünde bulundurulmasıdır. Çünkü artık çevrenin sadece iyi düzenlenmiş olması yeterli değildir. Kentsel mekânın bireylerini ve karmaşık toplum düzenini, isteklerini ve kent yaşamının işlevlerini yansıtması gereklidir. (Lynch, 20I7). Büyüklüğü, konumlanışı, oransal özellikleri ve geometrisi, onu çevreleyen binaların kütlesel özellikleri ve cepheleri, içinde ya da çevresinde yer alan doğal ögeler (su yüzeyleri, bitkiler, ağaçlar vb.), kent mobilyaları, yer döşemeleri vb. kentsel kamusal mekânın fiziksel özelliklerini (Oktay, 1990); sosyal etkileşime imkan vermesi, kullanıcılara farklı aktivite seçenekleri ${ }^{5}$ sunması ve kolaylıkla erişilebilir ulaşılabilir olması işlevsel özelliklerini (Whyte, 1980); kullanıcının mekânda hissettikleri, algı düzeyi vb. ise kentsel kamusal mekânın duyumsal özelliklerini tanımlamaktadır.

Bu bakış açısıyla çalışma kapsamında kuşakların kentsel kamusal mekânı tercih etme nedenleri kentsel kamusal mekânın özellikleri üzerinden sorgulanmış; fiziksel niteliği (büyüklük/ genişlik, zeminin yumuşak ya da sert olması, su ögesi ve niteliği, kent mobilyası özellikleri), sosyal niteliği/aktivite çeşitliliği (fiziksel ya da sosyal aktivite) ve psikolojik etkisi çalışmanın değişkenleri olarak belirlenmiştir.

Kentsel kamusal mekânın fiziksel niteliği: Mekânların biçimsel özellikleri kullanıcının o mekânı kullanıp kullanmamasını ya da kullanım şeklini (hareketli ya da durağan olma durumunu) belirleyen en temel unsurdur.

- Büyüklük/genişlik: Kentsel kamusal mekânın alansal büyüklüğü ile ilişkilidir. Binalar ile çevrili kentsel mekânın büyüklüğü; hem kullanıcının mekânsal algısını; dolayısıyla güven, aidiyet, mahremiyet, huzur gibi insani duygularını, hem de gerçekleştirilecek aktiviteyi ve kullanıcının bu yöndeki tercihini belirlemektedir.

- Yumuşak zemin/sert zemin: Trancik (1986) kentsel mekânı, sert ve yumuşak mekân olarak sınıflandırmıştır. Bu sınıflandırmada belirleyici öge mekânın zemininin ve sınırlayıcı (duvarlar ya da doğal çevre) elemanların niteliğidir. Sert mekânlar meydanlar, yumuşak mekânlar ise park, bahçe ve pasif yeşil bant olarak tanımlanan yeşil dokudan oluşur (Taşçı, 20I4). Yeşil dokuyu oluşturan bitkisel ve yapısal elemanların nitelik, form, ölçü, doku, renk gibi özellikleri kent mekânına fiziksel ve estetik değer sağlar. Bu nedenle yeşil doku arazinin engebeli ya da düz oluşuna, ağaçlık ya da çimenlik oluşuna ya da peyzaj özelliklerine göre; sert zemin ise büyüklüğüne ya da inişli çıkışlı olmasına göre nitelenebilir. Bunlar mekânda gerçekleştirilecek aktiviteyi ya da mekâna yönelik beklentiyi etkileyerek kullanıcı tercihinde belirleyici rol oynar.

- Su ögesi: Kentsel kamusal mekânın fiziksel niteliğini tanımlayan bir diğer öge kimi zaman estetik kimi zaman fonksiyonel amaçlı bir tasarım elemanı olarak kullanılan su ögesidir. Kullanıcıyı görsel, işitsel ve psikolojik anlamda etkileyen su ögesi pek çok farklı form ve biçimde mekânda yer alabilir. Algısal olarak en önemli özelliği huzur vermesi (Marlowe, 1977) olan suyun mekândaki varlığı; hareketli, sesli oluşu, işlevsel ya da estetik/görsel amaçlı kullanımı kullanıcıların kentsel mekâna yönelik tercihlerini etkilemektedir.

- Kent mobilyası: Kent mobilyası kentlilerin değişen ihtiyaçlarını karşılamak amacıyla tasarlanan; bilgi-iletişim panosundan çöp kutusuna, meydanlardaki objelere, çeşmeden telefon kulübesine kadar, işlevsel ve estetik/ görsel amaçlı obje veya objeler bütünüdür (Ilgın, 200I). Dolayısıyla sabit- hareketli, teknolojik-doğa ile uyumlu ya da uyumsuz olması kentsel mekânın fiziksel karakterini belirleyen özelliklerden biridir. Hem işlevsel hem de estetik amaçlı kullanılan kent mobilyaları, kentsel mekânın temizliğini, güvenliğini, konforunu ya da estetik değerini etkileyerek kullanıcının mekânsal tercihlerinde yönlendirici olur.

Kentsel kamusal mekândaki aktivite çeşitliliği: Mekân, içindeki toplumsal ilişkileri ortaya çıkararak analiz edilmelidir (Lefebvre, 20।4). Dolayısıyla sosyalleşme ve toplumsallaşma mekânı olarak kentsel kamusal mekânın fiziksel özelliklerinin sunduğu olanaklar, o mekândaki aktivitelerin neler olabileceğini belirler. Bu aktiviteler fiziksel ve sosyal aktiviteler olmak üzere sınıflandırılabilir.

- Fiziksel aktivite: Kentsel kamusal mekânda gerçekleştirilen fiziksel aktiviteler mekânın özelliklerine ve kullanıcının ihtiyaçlarına göre belirlenir. Tempolu yürüyüş, gezinti, koşma, paten kayma, top oyunları, uzanma, oyun oynama, bisiklete binme, yoga ve pilates gibi aktiviteler kentsel kamusal mekânda gerçekleştirilebilecek aktivitelerden bazılarıdır. Bu aktiviteler değişen yaşam tarzına göre değişim gösterebilir.

- Sosyal aktivite: Kentsel kamusal mekânlar bireylerin var olan faaliyetlere katıldıkları, formel ya da informel karşıIıklı ilişki kurdukları, tesadüflerin yaşanabileceği alanlardır (Gökgür, 2008). Bu alanlar insanlara diğerleri ile bir arada

\footnotetext{
4 Planlama literatüründe "kentsel kalite” ve "yaşanırık” kavramları genel hatlarıyla aynı anlama karşılık gelmekle beraber "yaşanırlık” bireylerin yaşamsal tatmin hissine doğrudan katkıda bulunan, mekânların niteliklerine ilişkin bir ilke olarak bireyin mekân kullanım tercihini artıracak bir kalite düzeyini tariflemektedir (Demir Kahraman 20I4). Rapoport (1982) mekânsal kaliteyi tasarımda fark edilen, göze çarpan farklılıklar olarak ele alırken, Van der Voort (2005) mekânsal kaliteyi ölçülebilir nesnel ve öznel nitelikleri kapsayacak şekilde işlevsel kalite (mekânın işlevlere uygunluğu), estetik kalite (mekânın güzelliği, teşvik ediciliği ve uyumu), ekonomik kalite (mekânın finansal kaynaklarının etkin kullanımı), teknik kalite (güveliği, sağlıklı olma durumu vb.) olarak tanımladığı dört ana başıkta incelenmiștir (Detaylı bilgi için bkz. Demir Kahraman, 20।4).

5 Gehl, dış mekânda gerçekleştirilebilecek aktiviteleri gerekli, opsiyonel ve sosyal aktiviteler olarak sıralamış, bu aktivitelerin gerçekleşmesini kentsel mekânın niteliği ile ilişkilendirmiştir. Buna göre özellikle opsiyonel ve sosyal aktivitelerin gerçekleştirilmesi mekânın nitelikleri ile doğrusal bir ilişkiye sahiptir (Detaylı bilgi için bkz. Gehl, I996).
} 
olma fırsatı sunarak birlikte olmanın, diğerlerini görmenin ve duymanın, onlardan etki almanın sağladığı deneyimler yaşatır. Bu anlamda toplumun yapılandığı, birey ve toplum arasındaki ilişkinin fiziksel çevre tarafından desteklendiği yerlerdir (Erdönmez ve Akı, 2005). Teknolojik gelişmeler, değişen iletişim şekilleri, sosyalleşme kavramını farklı mecralara taşıyarak mekâna yüklenen anlamları ya da sosyalleşme şekillerini değiştirse de halen kamusal mekânlar, kentin kimliğini, kente ait olma, kentli olma duygusunu ortaya çıkaran ve çoğaltan mekânlardır.

Kentsel kamusal mekânın psikolojik etkisi: Kentsel kamusal mekânın algılanabilir olması, insan ölçeğine uygun olması, kapalılı̆̆, sosyal imajı ya da mekânın kuşatılma derecesi kullanıcının kendisini güvende, yalnız ya da ait hissetmesi gibi duygu değişimlerini ve psikolojik durumu etkilemektedir. Her ne kadar mekânın görsel ve işlevsel çeşitliği genel olarak kullanıcıların psikolojik olarak gereksinim duyduğu (Uzgören ve Erdönmez, 2016) bir özellik olsa da mekânın dinlendirici/ sakin olması, hareketli olması, huzur verici olması, güvenli olması, kalabalık olması, sessiz /gürültülü olması da kullanıcının mekânsal tercihlerini etkileyen unsurlardır.

\subsection{Araştırmanın Yöntemi}

Araştırmanın yöntemi anket çalışması üzerine kurgulanmıştır. Anket formunda elde edilmesi hedeflenen bilgiler üç gruba ayrılmıştır. Buna göre dengeli bir örneklem oluşturulmak amacıyla ankette yer alan; kişilerin doğum tarihi, cinsiyet bilgisi gibi demografik veriler ilk grupta, mekânın kuşakların mekânsal tercihlerini etkileyen, fiziksel niteliği, sosyal niteliği/aktivite çeşitliliği ve psikolojik etkisi olarak sıralanan özellikleri ikinci grupta; kuşakların zamansal tercihleri ise üçüncü grupta sorgulanmıştır. Sorular çoktan seçmeli olarak düzenlenmiş, diğer seçeneğinin cevabı açık uçlu bırakılmıştır. Çalışmada $X, Y$ ve $Z$ kuşaklarının her birini temsil eden; demografik olarak dengeli bir dağılım gösteren 30'ar kişi ile toplam 90 anket yapılmıştır. Sonrasında her deneğin verdiği yanıtlara göre veriler kodlanmıştır. Analizler veriler arasındaki ilişkileri saptayacak istatiksel analiz programı SPSS kullanılarak temel istatiksel işlemlerle yapılmış, veriler ki-kare anlamlılık sınamasından geçirilmiştir.

Analiz çalışmasında kuşak değişimi bağımsız değişken olarak belirlenmiş, kuşak değişimi ile mekânsal tercihleri etkileyen değişkenler arasında anlamlı ilişki bulunup bulunmadığı ayrı ayrı sınanmıştır. Bu şekilde elde edilen veriler karşılaştırmalı bir bakış açısıyla nedensellikleri üzerinden değerlendirilmiştir. Böylece kentsel kamusal mekâna yönelik tasarımları etkileyecek yeni bakış açılarının ve önerilerin tartışıldığı bir ortam oluşturulmuştur.

\subsection{Araştırmanın Bulguları}

Araştırma verileri mekânın fiziksel niteliği, aktivite çeşitliliği, psikolojik etkisi ve kullanım zamanı ile ilişkili olmak üzere ayrı ayrı analiz edilmiştir. ${ }^{6}$ Buna göre kentsel kamusal mekânın fiziksel nitelikleri arasında yer alan büyüklük, yeşil doku, sert zemin büyüklüğü ve yükseltisi konusunda kuşakların eğilimleri oransal olarak farklılık göstermekle beraber benzerdir; çoğunlukla büyük ölçekli, çimenlik, çiçekli bitkilerin yer aldığı, sert zeminin az olduğu, düz kentsel kamusal mekânlar tercih edilmektedir. Ancak Z kuşağında sert zemini geniş ve kot farklılığı olan kentsel mekânı tercih eden kişi sayıları diğer kuşaklara göre daha yüksek oranlara sahiptir. Öte yandan $X$ kuşağı görsel amaçlı, $Y$ kuşağı dokunulabilir, $Z$ kuşağı ise hareketli su ögesini tercih ettiğini belirtmiştir. $\mathrm{Ki}^{2}$ anlamlılık testinde anlamlı bir ilişki saptanmasa da bu eğilimler kuşakların genel özellikleri ile paralellik göstermektedir. Sokak mobilyası olarak $X$ ve $Z$ kuşaklarının sabit, $Y$ kuşağının ise hareketli mobilya tercih ettiği saptanmıştır. Ayrıca kuşakların hepsi doğa ile uyumlu mobilya tercih ederken $X$ ve $Y$ kuşaklarının teknolojik olmayan, Z kuşağının ise teknolojik sokak mobilyası tercih ettiği anlaşılmaktadır. Bu veriler $\mathrm{ki}^{2}$ ile test edilmiş sokak mobilyasının teknolojik ya da sabit/hareketli olması ile kuşak değişimi arasında istatiksel açıdan anlamlı bir ilişki olduğu saptanmıştır (Tablo I).

Kentsel kamusal mekân tercihini etkileyen değişkenlerden aktivite çeşitliliği; fiziksel aktivite ve sosyal aktivite olmak üzere iki grupta ayrı ayrı analiz edilmiştir. Fiziksel aktivite açısından irdelendiğinde $X$ kuşağının kentsel kamusal mekânı daha çok yürüyüş ve gezinti amaçlı tercih ettiği, $Y$ kuşağının da benzer bir eğilim gösterdiği, ancak buna ek olarak oyunu da kentsel mekânda gerçekleştirilecek aktiviteler arasında kabul ettiği anlaşılmaktadır. $Z$ kuşağının ise yürüyüş ve gezintinin yanı sıra top oyunları koşma gibi daha dinamik etkinliklere yöneldiği belirlenmiştir. Bu farklılıklar $\mathrm{ki}^{2}$ ile test edilmiş, yürüyüş ve oyun ile kuşak değişimi arasında istatiksel açıdan anlamlı bir ilişki olduğu saptanmıştır (Tablo 2).

X, Y, Z kuşağının kentsel mekâna yönelik sosyal aktivite tercihlerinde sohbet seçeneğinin çoğu kullanıcı tarafından tercih edildiği belirlenmiştir. Bunun dışında $X$ kuşağının yeme içme; $Y$ kuşağının müzik dinlenme; $Z$ kuşağının ise buluşma gibi aktiviteleri de tercih ettikleri anlaşılmaktadır. Ayrıca kentsel kamusal mekânda müzik yapmanın Z kuşağının tercihlerini etkileyen değişkenler arasında yer aldığı da dikkat çekici bir başka bulgudur. Bu farklılıklar $\mathrm{ki}^{2}$ ile test edilmiş, yeme içme ile kuşak değişimi arasında anlamlı bir ilişki olduğu saptanmıştır (Tablo 3).

Analizlerde $X$ kuşağı için kentsel kamusal mekânın dinlendirici/sakin, güvenli ve huzur verici olmasının; $Y$ kuşağı için huzur

Katılımcılar her soru için birden fazla seçeneği işaretlemek konusunda özgür bırakılmışlardır. Dolayısıyla analizler ve değerlendirmeler oransal değil, sayısal verilere bağl kalınarak yapılmıştır. 
Tablo I. Kuşakların mekânın fiziksel niteliğine yönelik tercihleri

\begin{tabular}{|c|c|c|c|c|c|}
\hline Mekanın fiziksel niteliği & X kuşağı & Y kuşağı & Z kuşağı & Toplam & $\mathrm{ki}^{2} / \mathrm{p}$ değeri \\
\hline \multicolumn{6}{|l|}{ Büyüklük/genişlik } \\
\hline Büyük ölçekli & 22 & 24 & 23 & 69 & \multirow{2}{*}{0,83} \\
\hline Küçük ölçekli & 8 & 6 & 7 & 21 & \\
\hline \multicolumn{6}{|l|}{ Yeşil doku/arazi niteliği } \\
\hline Çimenlik & 16 & 16 & 20 & 52 & \multirow{2}{*}{0,483} \\
\hline Ağaçlık & 14 & 14 & 10 & 38 & \\
\hline \multicolumn{6}{|l|}{ Yeşil doku/bitki niteliği } \\
\hline Çiçekli bitki & 24 & 23 & 24 & 73 & \multirow{2}{*}{0,935} \\
\hline Çiçeksiz bitki & 6 & 7 & 6 & 19 & \\
\hline \multicolumn{6}{|l|}{ Sert zemin/büyüklük } \\
\hline Sert zemin fazla & 4 & 9 & 11 & 24 & \multirow{2}{*}{0,109} \\
\hline Sert zemin az & 26 & 21 & 19 & 66 & \\
\hline \multicolumn{6}{|l|}{ Sert zemin/yükselti } \\
\hline Kot farklılığı olan & 8 & II & 14 & 33 & \multirow{2}{*}{0,275} \\
\hline Düz sert zemin & 22 & 19 & 16 & 57 & \\
\hline \multicolumn{6}{|l|}{ Su öğesi } \\
\hline Hareketli & 9 & 9 & II & 29 & \multirow{4}{*}{0,552} \\
\hline Sesli & 4 & 4 & 3 & II & \\
\hline Dokunulabilir & 7 & 12 & 6 & 25 & \\
\hline Görsel amaçlı & 10 & 5 & 10 & 25 & \\
\hline \multicolumn{6}{|l|}{ Sokak mobilyası/çeşit } \\
\hline Sabit & 17 & 6 & 18 & $4 I$ & \multirow{2}{*}{0,003} \\
\hline Harekekli & 13 & 24 & 12 & 49 & \\
\hline \multicolumn{6}{|l|}{ Sokak mobilyası/nitelik } \\
\hline Teknolojik & 4 & 6 & 22 & 32 & \multirow{2}{*}{0,000} \\
\hline Teknolojik olmayan & 26 & 24 & 8 & 58 & \\
\hline Doğa ile uyumlu & 27 & 28 & 28 & & \multirow{3}{*}{0,856} \\
\hline Doğadan olmayan & 3 & 2 & 7 & 12 & \\
\hline Toplam & 150 & 150 & 150 & 452 & \\
\hline
\end{tabular}

verici, dinlendirici ve sessiz olmasının; Z kuşağı için ise huzur verici, dinlendirici ve güvenli olmasının öncelikli tercih nedenleri arasında yer aldığı belirlenmiştir. Dolayısıyla kuşakların kentsel mekâna yönelik tercihlerini yönlendiren psikolojik eğilimler benzerdir. Ancak önceliklerin sıralaması farklılaşmaktadır. Öte yandan anket verilerine göre $X$ ve $Z$ kuşağında az sayıda kişi tarafından da olsa hareketli kentsel kamusal mekânlar tercih edilmiş, $Y$ kuşağında bu seçenek kimse tarafından seçilmemiştir. Bu farklılıklar ki² ile test edildiğinde kentsel kamusal mekânın dinlendirici, hareketli ve sessiz olmasıyla kuşak değişimi arasında anlamlı bir ilişki olduğu saptanmıştır (Tablo 4).

Kullanıcıların kentsel kamusal mekâna yönelik zamansal tercihleri analiz edildiğinde ise kuşakların hepsinin öğleden sonra, 2 saatten fazla ve çoğunlukla bahar-yaz aylarında kentsel kamusal mekânı kullanma eğiliminde oldukları saptanmıştır. Bu veriler $\mathrm{ki}^{2}$ ile test edildiğinde sadece mevsimsel tercihler ile kuşaklar arasında anlamlı ilişki bulunduğu belirlenmiştir (Tablo 5).

\subsection{Değerlendirme}

Araştırmanın bulgularına göre kuşakların hepsinin kentsel mekânın büyüklüğü, yeşil dokunun niteliği, sert zemin büyüklüğü ve yükselti durumu konusundaki tercihleri benzer olmakla beraber; Z kuşağında sert zeminin ve yükseltinin fazla (I I kişi), su ögesinin hareketli ( I I kişi) olmasını tercih eden kişi sayısı diğer kuşaklardan fazladır. Bu sonuçlarda Z kuşağının 
Tablo 2. Kuşakların fiziksel aktivite tercihleri

\begin{tabular}{lccccc}
\hline Fiziksel aktivite & X kuşă̆ı & Y kuşă̆ı & Z kuşă̆ı & Toplam & ki'/p değeri \\
\hline Yürüyüş & 25 & 19 & 13 & 57 & 0,006 \\
Gezinti & 20 & 19 & 14 & 53 & 0,241 \\
Koşma & 8 & 3 & 12 & 23 & 0,052 \\
Top oyunları & 6 & 9 & 10 & 25 & 19 \\
Uzanma & 4 & 8 & 7 & 26 & 0,487 \\
Oyun & 3 & 15 & 7 & 24 & 0,003 \\
Bisiklete binme & 7 & 10 & 71 & 227 & 0,6 \\
Toplam & 79 & 83 & &
\end{tabular}

Tablo 3. Kuşakların sosyal aktivite tercihleri

\begin{tabular}{|c|c|c|c|c|c|}
\hline Fiziksel aktivite & X kuşağı & Y kuşağı & Z kuşağı & Toplam & $\mathrm{ki}^{2} / \mathrm{p}$ değeri \\
\hline Sohbet & 26 & 19 & 18 & 63 & 0,046 \\
\hline Sanatsal etkinlik & 9 & 9 & 10 & 28 & 0,949 \\
\hline Etrafı seyretme & II & II & 7 & 29 & 0,443 \\
\hline Buluşma & 19 & 12 & 20 & 51 & 0,76 \\
\hline Müzek dinleme & 15 & 23 & 15 & 53 & 0,053 \\
\hline Müzik yapma & I & 2 & 8 & II & 0,12 \\
\hline Yeme-içme & 23 & 11 & 13 & 47 & 0,004 \\
\hline Toplam & 104 & 87 & 91 & & \\
\hline
\end{tabular}

Tablo 4. Kentsel kamusal mekânın, kuşakların tercihlerini yönlendiren psikolojik etkileri

\begin{tabular}{|c|c|c|c|c|c|}
\hline Psikolojik etki & X kuşağı & Y kuşağı & Z kuşağı & Toplam & $\mathrm{ki}^{2} / \mathrm{p}$ değeri \\
\hline Dinlendirici & 27 & 20 & 17 & 64 & 0,014 \\
\hline Hareketli & 5 & 0 & 6 & II & 0,043 \\
\hline Huzur verici & 19 & 23 & 19 & 61 & 0,443 \\
\hline Güvenli & 20 & 17 & 15 & 52 & 0,421 \\
\hline Sessiz & 10 & 20 & 11 & 41 & 0,017 \\
\hline Toplam & 81 & 80 & 68 & 229 & \\
\hline
\end{tabular}

yaratıcılığı, otoriteyi genel eğilimleri önemsememe ve birden fazla aktiviteyi aynı anda gerçekleştirebilme, çabuk tüketme ve sürekli arayış içinde olma özelliğinin etkili olduğu düşünülmektedir. Çünkü özgürlüğüne önem veren $Z$ kuşağı için mekânın hareketli olması aktiviteleri çeşitlendirecek bir potansiyel sunmaktadır. Öte yandan $X$ ve $Y$ kuşağı sokak mobilyasının teknolojik olmasını önemsemezken teknolojinin bulunmadığı ortamlarda kendini rahatsız ve eksik hisseden Z kuşağı için teknolojik sokak mobilyası ve teknolojiye ulaşılabilirlik (22 kişi) önemli bir tercih nedenidir. Çünkü Z kuşağı için teknoloji hayatın her anında yanlarında ve kullanılabilir olmalıdır.
Ayrıca bahsi geçen kişilik özellikleri nedeniyle Z kuşağının fiziksel aktivite tercihlerinde de farklılıklar olduğu; koşma ( 12 kişi) ve top oyunları (10 kişi) gibi dinamik, hareketli aktiviteleri de tercih ettikleri, yaratıcı yönlerinin de etkisiyle kentsel mekândan beklentilerini genel eğilimlerin dışına çıkarak çeşitlendirdikleri anlaşılmaktadır. Öte yandan oyunu (I5 kişi) kentsel kamusal mekânda gerçekleştirilecek bir aktivite olarak kabul eden $Y$ kuşağının bu tercihinde güçlü sosyal ilişki kurma becerisinin, hızlı düşünme ve hareket etme özelliklerinin etkili olduğu düşünülmektedir. Anket verileri sosyal aktivite tercihlerinin $X$ ve $Y$ kuşakları için benzer olduğunu 
Tablo 5. Kullanıcıların kentsel kamusal mekâna yönelik zamansal tercihleri

\begin{tabular}{|c|c|c|c|c|c|}
\hline Zamansal tercihler & X kuşağı & Y kuşağı & Z kuşağı & Toplam & $\mathbf{k i}^{2} / p$ değeri \\
\hline \multicolumn{6}{|l|}{ Kullanım süresi } \\
\hline Ögleden önce & 14 & 12 & 9 & 35 & \multirow{2}{*}{0,721} \\
\hline Öğleden sonra & 16 & 18 & 21 & 55 & \\
\hline \multicolumn{6}{|l|}{ Kullanım zamanı } \\
\hline 2 satten az & 13 & 10 & 12 & 35 & \multirow{2}{*}{$0,41 I$} \\
\hline 2 saatten fazla & 17 & 20 & 18 & 55 & \\
\hline \multicolumn{6}{|l|}{ Mevsimsel tercih } \\
\hline Bahar & 19 & 16 & 10 & 45 & \multirow{3}{*}{0,001} \\
\hline Yaz & 3 & 11 & 18 & 32 & \\
\hline Kış & 8 & 3 & 2 & 13 & \\
\hline Toplam & 90 & 90 & 90 & 270 & \\
\hline
\end{tabular}

ortaya koyarken pragmatik, çözüm odaklı düşünce yapısı ile $X$ kuşağının yeme içmeyi (23 kişi), $Y$ kuşağının ise otoriteye tepkili, özgür yapısıyla müzik dinlemeyi (23 kişi) tercih ettiği bilgisini vermektedir. Bunun dışında $Z$ kuşağının müzik dinlemek (I5 kişi) kadar müzik yapmayı (8 kişi) da kentsel kamusal mekânda gerçekleştirilecek aktiviteler arasında kabul etmesinde özgür, otorite tanımaz, yaratıcı kişilik özelliklerinin etkili olduğu düşünülmektedir.

Kuşakların kentsel mekâna yönelik tercihlerini belirleyen psikolojik eğilimler farklı oranlarda ve sıralamada olsa da benzer bir eğilimi tariflemektedir. Bu durum toplumun geneline yayılan güvenlik kaygısının, yabancılaşmanın ve yalnızlaşmanın psikolojik etkilerinin yansıması olarak yorumlanabilir. Diğer taraftan Y kuşağının kentsel kamusal mekânın sessiz (20 kişi) ve dinlendirici ( $20 \mathrm{kişi})$ olmasını önemli bir tercih nedeni olarak belirtmesi daha özgür, daha iş odaklı ve yoğun çalışan bir kuşak olması ile ilişkilendirilebilir.

Araştırma bulgularına göre kuşaklar arasında zamansal tercihlerin genel olarak benzer bir eğilim gösterdiği, ancak Z kuşağının mevsimsel tercihinin farklılaştı̆̆ı belirlenmiştir. Tercihlerin benzer olmasında her kuşak için çalışma saatlerinin, yıllık izin kullanma zamanlarının ve hava sıcaklıklarının belirlediği genel eğilimlerin paralelliği; Z kuşağının mevsimsel tercihlerinin farklılaşmasında ise bu kuşağın halen eğitimini sürdürüyor olması ve tatillerinin yaz aylarında olmasının etkili olduğu düşünülmektedir.

\section{Sonuç}

Araştırmanın bulgularına göre kuşakların kentsel kamusal mekâna yönelik tercihlerinde benzer eğilimlerin yanı sıra farklılaşan eğilimler de belirleyicidir. Özellikle toplumdaki en genç kuşak olarak $Z$ kuşağının teknolojiye bağımlılı̆ı, sosyal ilişki biçimi, özgür ve sınır tanımaz hareket ihtiyacı gibi kişilik özelliklerinin kentsel kamusal mekâna yönelik tercihlerinde de farklı öncelikleri ortaya çıkardığı dikkat çekmektedir. Dolayısıyla yeni kuşağın farklı istek ve ihtiyaçlarının yeni planlama yaklaşımlarını gerekli kıldığını söylemek mümkündür. Bu anlamda kentsel kamusal mekânın tasarım sürecinde genel eğilimler dışında kuşakların mekânsal tercihlerinin de analiz edilmesi önemli ve öncelikli tasarım aşamalarından biri olarak kabul edilmelidir. Tasarımın, sosyolojik boyutu ile ilişkili olarak, kimin için hangi önceliklerle yapıldığını belirleyen bu aşamada elde edilen veriler yönlendirici olmalı; doğaya, yere ve yerleşiklere saygılı ancak teknolojik anlamda güncel olanakları kullanan ve sunan, zamana uyumlu, esnek mekânlar düzenlenmelidir. Kullanıcının aktif katılımının sağlandığı böyle bir planlama süreci ile farklı kuşakların ihtiyaçlarını ve beklentilerini karşılayan, değişen toplumsal koşullara uyumlu, zamansız kentsel mekânlar elde edilebilecektir. 


\section{KAYNAKLAR}

Ayhün, S. E. (2013). Kuşaklar arasındaki farkllılklar ve örgütsel yansımaları. Ekonomi ve Yönetim Araştırmaları Dergisi, 2/1, 93-112.

Bezirci, S. Ş. (2012). Farklı kuşaklardaki hemşirelerin meslekten ve işten ayrılma niyetleri ile iş doyumlarının incelenmesi. (Yayınlanmamış yüksek lisans tezi). Dokuz Eylül Üniversitesi Sağllk Bilimleri Enstitüsü, İzmir.

Carr, S., Francis, M., Rivlin, L.G., Stone, A.M. (1992). Public space. Cambridge: Cambridge University Press.

Chicca, J., Shellenbarger, T. (2018). Generation Z: Approaches and teachinglearning practices for nursing professional development practitioners. Journal for Nurses in Professional Development, 34/5, 250-256.

Coupland, D. (1989, Haziran). The young and restless work force following the baby boom: Generation X, Vista dergisi. Erişim adresi: http://joeclark.org/dossiers/ GenerationX.pdf. (04.02.2020).

Cullen, G. (1961). Townscape. London: The Architectural Press.

Çetin Aydın, G., Başol, O. (2014). X ve Y kuşağı: Çalışmanın anlamında bir değişme var mı?. Electronic Journal of Vocational Colleges, Aralık, 1-15.

Çubuk, M. (1991). Kamu mekânları ve kentsel tasarım. M.S.Ü. Kamu Mekânları Tasarımı ve Mobilyaları Sempozyumu. İstanbul, 15-17.

Demir Kahraman, M. (2014). İnsan ihtiyaçları ve mekansal elverişlilik kavramları perspektifinde yaşanılırlık olgusu ve mekansal kalite. Planlama Dergisi, 24/2, 74-84.

Düzenli, E, Yılmaz S., Alpak M. (2020). Dosya; X,Y,Z Kuşaklarının kentsel açık mekân kullanımları, Plant Dergisi, Şubat, 76-81.

Elmore, L. (2011). Competing for jobs when you're up against your mum, your grandpa, and your pers. Women In Business, Summer, 37-39.

Erdönmez M.E., Akı, A. (2005). Açık kamusal kent mekânlarının toplum ilişkilerindeki yeri. Megaron Y.T.U. Mim. Fak. E-Dergisi, 1/1, 67-87.

Erdönmez, E. (2014). Kamusal alan ve toplum. İstanbul: İlbey Matbaası.

Erzen, J.N. (2019). Üç habitus yeryüzü, kent, yapı. İstanbul: Y.K.Y. Yayınları.

Etlican, G. (2012). X ve Y kuşaklarının online eğitim teknolojilerine karşı tutumlarının karşılaştııılması. (Yayınlanmamış yüksek lisans tezi). Bahçeşehir Üniversitesi, Sosyal Bilimler Enstitüsü, İstanbul.

Gehl, J. (1989). A changing street life in a chaging society. Places, 6/8, 8-17.

Gehl,J. (1996). Life between buildings: Using public space. Washington:Island Press.

Gökgür, P. (2008). Kentsel mekânda kamusal alanın yeri. İstanbul: Bağlam Yayınclik.

Howe, N., Strauss W. (2007, Haziran). Helicopter parents in the workplace. Erişim adresi: www.newparadigm.com (10.02.2020).

Ilgın, İ. D. (2001). Tasarım eğitimi: Yaratıcılığı desteklemek. DomusM, 10/10.

İnceoğlu, M., Aytuğ, A. (2009). Kentsel mekanda kalite kavramı. Megaron Y.T.U. Mim. Fak. E-Dergisi, 4/3, 131-146.

Jianrui, J. (2011). Y factor: managing the new generation of soldiers. Journal of the Singapore Armed Forces, 39/4, 53-59.

Joedicke, J. (1985). Raum und Form in der Architektur: Ä Uber den behutsamen Umgan mit der Vergangenheit [Space and Form in Architecture]. Stuttgart, Germany: Kraemer.

Keleş, N.H. (2011). Y Kuşağı çalışanlarının motivasyon profillerinin belirlenmesine yönelik bir araştırma. Organizasyon ve Yönetim Bilimleri Dergisi, 3/2,129-139.

Kon, B. (2017,Haziran).Kuşakları anlamakve yönetmek. Erişim adresi: http:// www.humanica.com.tr/kusaklari-anlamak-yonetmek (12.02.2020).

Krier, R. (1979). Urban space. New York: Rizzoli.

Kuran, E. (2018). Telgraftan tablete. İstanbul: Destek Yayınları.

Kuru, İ. (2014). Y kuşağı ve iş yaşam dengesi. (Yayınlanmamış yüksek lisans tezi). Bahçeşehir Üniversitesi, Sosyal Bilimler Enstitüsü, İstanbul.

Lang, J. (1994). Urban design: The American experience. New York: Van Nostrand Reinhold.

Lefebvre, H. (2014). Mekânın üretimi (I. Ergüden, Çev.), İstanbul: Sel Yayincilik.
Lynch, K. (2017). Kent imgesi. İstanbul: Türkiye İş Bankası Yayınları.

Mannheim, K. (1998). Collected works of Karl Mannheim; V.5. P. Kecskemeti (Yay.haz.), New York: Routledge.

Marlove, O.C. (1977). Outdoor design. London: Granada Publishing Limited.

Mengi, Z. (2009, Haziran). Z kuşağı geliyor. Erişim adresi: http://www.zeynepmengi.com/ 2012/06/z-kusagi-geliyor/ (14.03.2020).

Morgan, C. N. (2011). Generational differences in the workplace, KY: Midwest Academy of Management Louisville.

Oktay, D. (1990). Kentsel kamu mekânlarının sosyal işlevlerini güçlendirme amaçlı tasarımı için bir yöntem araştırması. (Yayınlanmamış doktora tezi). Yıldız Teknik Üniversitesi, Fen Bilimleri Enstitüsü, İstanbul.

Parry, E., Urvin, P. (2010). Generational differences in work values: a review of theory and evidence'. International Journal of Management Reviews, $13 / 1,79-96$

Raines, C. (2002, Haziran). Managing millennials in connecting generations. Erişim adresi: http://www. generationsatwork.com/articles/millenials. htm (14.02.2020).

Rapoport, A. (1977). Human aspects of urban form: towards a manenvironment approach to urban form and design, Newyork: Pergamon Press.

Rapoport, A. (1982). The meaning of the built environment: A nonverbal communication. Beverly Hills, C.A.: Sage Publications.

Reeves, T. C., Oh, E. (2008). Generational differences. Handbook of Research on Educational Communications and Technology, 3, 295-303.

Sheahan, P. (2005). Generation Y: Surviving (and Thriving) with generation Y at work. Australia: Hardie Grant Books.

Strauss, W., Howe, N. (1991). Generations: The history of America's future. New York.

Tanyeli U. (2009). Türkiyénin görsellik tarihine giriş. İstanbul: Ofset Bask1.

Taş̧̧, H. (2014). Bir hayat tarzı olarak şehir, mekân, meydan. İstanbul: Kaktüs Yayınları.

Tessler, M., Konold, C., Reif, M.E. (2004). Political generations in developing countries: Evidence and insights from Algeria. Public Opinion Quarterly, $68 / 2,184-216$

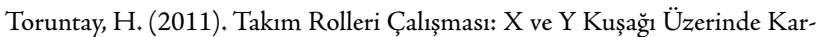
şılaştırmalı Bir Araştırma. (Yayınlanmamış yüksek lisans tezi). İstanbul Üniversitesi, Sosyal Bilimler Enstitüsü, İstanbul.

Trancik, R. (1986). Finding Lost Space. Canada: John Wiley and Sons Inc.

Türk, A. (2013). Y Kuşağı. İstanbul: Kafe Kültür Yayıncılık.

Twenge, J.M., Campell, S.M., Hoffman B.J., Lance C.E. (2010). generational differences in work value: leisure and extrinsic value increasing, social and intrinsic value decreasing, Journal of Management, 36/5, 1117-1147.

URL 1 http://www.tdk.gov.tr/ (02.05.2020)

URL 2 http://www.lifecourse.com/insight/phases.html (10.06.2020)

URL 3 http://www.wikipedia.org (18.06.2020)

URL 4 http://www.tuik.gov.tr/UstMenu.do?metod=temelist (05.07.2020)

Uzgören, G., Erdönmez, E. (2016). Kamusal açık alanlarda mekân kalitesi ve kentsel mekân aktiviteleri ilişkileri üzerine karşılaştırmalı bir inceleme. Megaron Y.T.U. Mim. Fak. E-Dergisi, 12/1, 41-56.

Voordt, D. J. M. van der. (2005). Architecture in use: An introduction to the programming design and evaluation of buildings. Amsterdam: Architectural Press.

Wendover, R.W. (1996). Managing Millennials. Erişim adresi: http://www. gentrends. com/Articles/Instore1996/Managing\%20Millennialscolumn.pdf

Whyte, W.H. (1980). The social life of small urban spaces. Washington DC:Conservation Foundation.

Wolburg, J. M., Pokrywczynski, P. A. (2001). Psychographic analysis of generation y college students. Journal of Advertising Research, 41/5, 33-53.

Zevi, B. (1990). Mimariyi Görmeyi Öğrenmek. (D. Divanlıoğlu, Çev.), İstanbul: Birsen Yayınları. 